\title{
Multimedia for Improving Competency of Business Presentations: A Brief Literature Review
}

\author{
Nurdin Hidayat \\ Department of Economic \\ Education \\ STKIP PGRI Bandar Lampung \\ Lampung, Indonesia \\ nurdinstkippgribl@gmail.com
}

\author{
Suroto* \\ Department of Economic \\ Education \\ Lampung University \\ Lampung, Indonesia \\ suroto.1993@fkip.unila.ac.id
}

\begin{abstract}
Vocational High School (SMK) graduates should find it easier to find work. This is because the skills and abilities of students are prioritized when studying at SMK. However, when viewed from the last level of education, unemployment in Indonesia is dominated by SMK graduates. This phenomenon shows that learning in SMK must be corrected immediately. This study aims to provide an overview of multimedia learning in improving the business presentation competence of vocational students. This study uses a literature study related to multimedia business presentations from several online research sources. Research reveals that multimedia that is designed according to the criteria of need can be effective in increasing the competence of business presentations. Making multimedia learning should be based on two strategic principles, namely giving control to students and giving visual cues.
\end{abstract}

Keywords-Multimedia, Competence, Business Presentations

\section{INTRODUCTION}

In recent years, labor competition has become increasingly fierce. This competition has caused a lot of unemployment. As we all know, SMK as a vocational education institution is expected to reduce the number of unemployed by providing students with more abilities to students. However, on the contrary, BPS data [1] shows that SMK contributed 1,348,327 people, or $19 \%$ of the total unemployed, which indicates that the skills of SMK students are inadequate.

Skill development in the form of technology, education, and vocational training is one of the key issues in dealing with skill deficiencies [2]. A vocational school that can be easily filled to achieve the desired graduate qualification must teach basic skills and individual professional skills to help in finding a job or starting a business [3]
Business presentation is one of the competencies that can affect student success [4]. Business presentation is one of the abilities that must be possessed by SMK graduates majoring in marketing. Students who have excellent business presentation skills will find it a lot easier to get a job [5]. It is necessary to increase the competence of business presentations to equip students for successful careers.

Multimedia is a medium with many tangible advantages, especially from an education and training perspective [6]. Several studies on the effectiveness of multimedia in education and training show that the diversity of visualization and animation can be an advantage of multimedia [7-9]. This study aims to determine the strategies and criteria that must be considered so that the use of multimedia can be effective in learning. The study in this study is expected to make a real contribution to the strategies and criteria that the teacher needs to pay attention to so that the multimedia used in learning can be effective in increasing the competence of students' business presentations.

\section{METHOD}

This study uses a literature review method to collect relevant data related to multimedia business presentations from several sources of books, articles, and research journals. The literature used is the source published in 2001-2019.

The research begins by determining the search keywords, then searching the data through the books and search engine applications that have been determined (Google Scholar, Research Gate, Science Direct, and Ebsco). Based on the sources obtained, it is known that the multimedia criteria are effective for improving the competence of business presentations. 


\section{RESULT AND DISCUSSION}

\section{A. Multimedia in Improving Presentation Communication}

Business presentation skills are one of the skills of a business communication subject, that is, a subject included in the vocational high school (SMK) curriculum. Competencies consist of the acquisition of knowledge, skills, values, and attitudes [10]. Student abilities can be achieved through learning. Learning is the process of interaction between students and educators and learning resources in a learning environment. Teachers need to be prepared for learning, as learning in Law No. 20 of 2003 can have a relatively lasting impact on the behavior, knowledge, and reasoning skills that arise through experience.

Good learning can be realized by the connection of various learning components such as objectives, materials, methods, and evaluation in learning [11]. Multimedia can be effective in improving student competence $[12,13]$. Multimedia can combine various types of digital media such as text, images, sound, and video, into multi-sensory integrated interactive applications or presentations to convey messages or information to the audience $[14,15]$. Multimedia is the simultaneous use of two or more different media forms [16]. Furthermore, Smaldino, Russel, Heinich, \& Molenda [17] state that multimedia is a collection of material that involves more than one type of media and is organized into a topic.

In computer-primarily based studying environments consisting of online studying structures or digital worlds, records may be provided to college students in lots of forms [18], consisting of text, sound, illustrations, diagrams, animations, and films at the screen. The mixture of all or a part of the media is known as multimedia. Mayer [19] makes use of the illustration mode view to outline multimedia as "representing cloth in verbal and visible form". From this huge perspective, multimedia isn't restrained to computer-primarily based environments. Text and visualization in the print layout also can be appeared as media.

In addition, if text and images are presented together with other technology-based media (for example, animation and computer-based narrative), students can learn best from multimedia. With the advancement of technology, various forms of information presented on mobile devices can also be classified as multimedia. For example, using mobile phones, students can learn about various things through apps. This type of application can also be classified as multimedia. The term multimedia refers to information media presented in various forms, most of which are based on technology.

\section{B. Understand the Strategy for Making Multimedia Business Presentations}

Learning multimedia must be able to play its function and role for the realization of effective learning. Whether software is good or not, usually shows how the quality of the software is [20]. Multimedia needs to be designed and developed by following the correct rules and elements. Smaldino, Lowther, \& Russel [21] state that compiling learning multimedia must consider the following:

- The content in the developed multimedia must balance fundamental abilities with higher-order thinking and be by the curriculum.

- The content in the developed multimedia must stimulate and lead students into the learning process.

- The content in the developed multimedia must offer interdisciplinary and multisensory patterns for learning and help students answer problems.

- The content in the developed multimedia must contain information and lead to independent conclusions

- The content in the developed multimedia must be a source of knowledge building for learners.

In addition to several aspects that must be considered, multimedia that is compiled should meet the multimedia criteria [22] as follows:

- Ease of navigation. A multimedia CD should be designed as simple as possible so that it is easy to learn.

- The content of cognition. There is a clear content of knowledge.

- Presentation of information, which is used to assess the content and multimedia program itself.

- Media integration, the media must integrate all aspects of knowledge and skills.

- Art and aesthetics. To attract learning interest, the program must have an attractive appearance and good aesthetics.

- The overall function, in other words, the program being developed must provide the learning abilities required by the students.

Based on the explanation above, the learning multimedia assessment criteria include several aspects, namely a) ease of navigation so that students can learn it easily, b) the content of cognition, namely multimedia must contain clear knowledge, c) presentation of information that functions to assess content, d) media integration to integrate knowledge and skills, e) artistic and aesthetic to have an attractive appearance and good value, $\mathrm{f}$ ) overall function so that learning is by learning objectives.

Based on well-designed research, researchers have proposed several evidence-based principles to guide the research and practice of multimedia presentations [8]. 
These principles provide teachers, educational designers, and developers with a solid foundation for understanding strategies for creating multimedia.

\section{1) Provide student control}

Student management is the first strategy when creating multimedia [23]. According to Betrancourt [24], students have student controls to control the speed and direction of multimedia presentations. This is very important for learning when using dynamic visualizations (animations, videos, etc.) to convey instructions in a learning environment. Since the animation is temporary, you may not fully understand the information contained in the animation once the animation information is displayed. By providing controls (such as play and pause buttons), students can watch the animation again and return to receiving instructions. If the student decides they need it, they can watch the animation a third or fourth time. The results of some studies provide empirical evidence for this design strategy [25-28]. For example, Evans and Gibbons [25] discovered that students could use interactive diagrams to control the display of segments of text and material. This can facilitate deep learning. A study by Boucheix and Schneider [29] provides some evidence that a series of static graphs can be integrated with student controls to improve student comprehension.

\section{2) Visual cues (or "signaling")}

Visual cues (or "signals") are another strategy for making effective multimedia presentations for teaching and training. It is a technology that adds signal equipment to the learning environment to guide learners to pay attention to important information. It is not difficult to imagine a situation in which students are presented with many elements in multimedia, such as text on the screen, narration, animation, control buttons, navigation links, and other elements, which can perceptually guide the learner's attention. . Important information not related to learning. Therefore, instructional developers need to use visual cues to guide learners' attention. For example, Lin and Atkinson [30] used arrows to indicate important information presented in animation, and they found that clues can be effectively used for learning. Nelson, Kim, Foshee \& Slack [31] found that students have lower psychological needs in the virtual world. The current literature provides other empirical evidence to support the use of visual cues as a strategy for effective multimedia presentations (for example, Lin, Atkinson, Savenye, and Nelson [31]. The learning principle based on this is called the "signal principle" [32].

Based on the above explanation, we need to consider two strategies. That is, to provide students with control and visual clues to create effective multimedia presentations. Both strategies are multimedia-specific, but there are other strategies worth mentioning. For example, when designing and developing multimedia, visualizations need to be closely aligned with the relevant text to limit attention. Graphics with linguistic narration are superior to graphics with text on the screen to optimize information processing in the learner's cognitive system. Segment your animation better to overcome the temporary nature of transitions. All of these strategies are based on evidence-based learning principles in the multimedia learning literature [19].

\section{CONCLUSION}

Multimedia can effectively improve the competence of vocational students' business presentations because multimedia combines various types of digital media such as text, images, sound, and video, into an integrated interactive application. For multimedia to be effective in improving the competence of students in making multimedia, they must pay attention to certain criteria and strategies such as student control and visual cues.

\section{REFERENCES}

[1] BPS, "Tingkat Pengangguran Terbuka Berdasarkan Tingkat Pendidikan, 2015 - 2018,” bps.go.id, 2018. https://www.bps.go.id/dynamictable/2018/05/17 00:00:00/1321/tingkat-pengangguran-terbuka-berdasarkantingkat-pendidikan-2015---2018.html.

[2] M. Grosch, "Developing a Competency Standard for TVET Teacher Education in ASEAN Countries," J. Pendidik. Teknol. dan Kejuru., vol. 23, no. 3, pp. 279-287, 2017, doi: 10.21831/jptk.v23i3.13418.

[3] Suroto, Susilaningsih, and Harini, "Toward Successful Career of Vocational Education Students through Improving Business Communication Skills Suroto 1, Susilaningsih 1 , Harini 1 1," Int. Conf. Teach. Train. Educ. 2017 (ICTTE 2017), vol. 158, no. Ictte, pp. 730-735, 2017, doi: https://doi.org/10.2991/ictte17.2017.107.

[4] J. Markowitsch and C. Plaimauer, "Descriptors for competence: Towards an international standard classification for skills and competences," J. Eur. Ind. Train., vol. 33, no. 8, pp. 817-837, 2009, doi: 10.1108/03090590910993652.

[5] V. Tūtlys and G. Spöttl, "From the analysis of work-processes to designing competence-based occupational standards and vocational curricula," Eur. J. Train. Dev., vol. 41, no. 1, pp. 50-66, 2017, doi: 10.1108/EJTD-10-2015-0078.

[6] N. Çolakoğlu and E. Atabay, "Job satisfaction of the academic staff of the vocational schools of the foundation and public universities: Sample of Turkey," Qual. Assur. Educ., vol. 22, no. 2, pp. 185-206, 2014, doi: 10.1108/QAE-12-2012-0050.

[7] R. Ploetzner and R. Lowe, "A systematic characterisation of expository animations," Comput. Human Behav., vol. 28, no. 3, pp. 781-794, 2012, doi: 10.1016/j.chb.2011.12.001.

[8] R. E. Mayer, M. Hegarty, S. Mayer, and J. Campbell, "When static media promote active learning: Annotated illustrations versus narrated animations in multimedia instruction," J. Exp. Psychol. Appl., vol. 11, no. 4, pp. 256-265, 2005, doi: 10.1037/1076-898X.11.4.256

[9] T. N. Höffler and D. Leutner, "Instructional animation versus static pictures: A meta-analysis," Learn. Instr., vol. 17, no. 6, pp. 722-738, 2007, doi: 10.1016/j.learninstruc.2007.09.013.

[10] E. Mulyasa, Pengembangan dan Implementasi Kurikulum 2013. Bandung: PT. Remaja Rosdakarya, 2013.

[11] Rusman, D. Kurniawan, and C. Riyana, Pembelajaran Berbasis TIK. Jakarta: Raja Grafindo Persada, 2013.

[12] K. Scheiter, C. Schubert, A. Schüler, H. Schmidt, G. Zimmermann, B. Wassermann, ... \& T. Eder. Adaptive 
multimedia: Using gaze-contingent instructional guidance to provide personalized processing support. Computers \& Education, 139, 2019. 31-47. 10.1016/j.compedu.2019.05.005.

[13] M. F. Lee, S. N. M. Yusoff, and K. H. Tan, "Needham model based instructional multimedia material for teaching digital logic gates," J. Tech. Educ. Train., vol. 11, no. 1, pp. 54-62, 2019, doi: 10.30880/jtet.2019.11.01.007.

[14] T. McEwan and Caincross Sandra, "Evaluation and Multimedia Learning Objects: Towards a Human-Centred Approach," 2004.

[15] T. K. Neo Ken and M. Neo, "Classroom innovation: Engaging students in interactive multimedia learning," Campus-Wide Inf. Syst., vol. 21, no. 3, pp. 118-124, 2004, doi: $10.1108 / 10650740410544018$.

[16] P. Zentel, M. Opfermann, and J. Krewinkel, "Multimedia Learning and The Internet: Ensuring Accessibility for People with Learning Disabilities," J. Assist. Technol., vol. 1, no. 1, pp. 22-32, 2007.

[17] S. Smaldino, J. . Russell, R. Heinich, and M. Molenda, Instructional Technology and Media for Learning, 8th ed. New Jersey: Merrill Prentice Hall, 2005.

[18] N. Listiana and A. A. Jaharadak, "Blended Learning as Instructional Media: Literature Review," J. Phys. Conf. Ser., vol. 1167 , no. 1,2019 , doi: 10.1088/17426596/1167/1/012066.

[19] R. E. Mayer, "Introduction to multimedia learning," Cambridge Handb. Multimed. Learn. Second Ed., pp. 1-24, 2014, doi: 10.1017/CBO9781139547369.002.

[20] E. P. Widoyoko, Evaluasi Program Pembelajaran: Panduan Praktis Bagi Pendidik dan Calon Pendidik, 4th ed. Yogyakarta: Pustaka Pelajar, 2014.

[21] S. Smaldino, D. L. Lowther, and J. . Russel, Instructional Technology \& Media for Learning: Teknologi Pembelajaran dan Media untuk Belajar, 9th ed. Jakarta: Kencana Prenademedia Group. (InstructionalTechnology and Media for Learning Pearson Education, Inc.), 2014.

[22] T. L. Leacock and J. C. Nesbit, "A Framework for Evaluating the Quality of Multimedia Learning Resources- Special Issue on 'Quality Research for Learning, Education, and Training,"' J. Educ. Technol. Soc., vol. 10, no. 2, p. 15, 2007, [Online]. Available:

http://www.sfu.ca/ jcnesbit/articles/LeacockNesbit2007.pdf.
[23] R. C. Clark and R. E. Mayer, E-learning and the science of instruction: Proven guidelines for consumers and designers of multimedia learning. San Fransisco, CA: Pfeiffer, 2011.

[24] M. Betrancourt and R. E. Mayer, "The Animation and Interactivity principles in Multimedia Learning," Cambridge Handb. Multimed. Learn., pp. 287-295, 2005, [Online]. Available:

http://steinhardtapps.es.its.nyu.edu/create/courses/2015/readin g/Betrancourt.pdf.

[25] C. Evans and N. J. Gibbons, "The interactivity effect in multimedia learning," Comput. Educ., vol. 49, no. 4, pp. 11471160, 2007, doi: 10.1016/j.compedu.2006.01.008.

[26] H. A. Taylor, D. N. Rapp, and T. A. D. T. Brunye, "Repetition and Dual Coding in Procedural Multimedia Presentations," Appl. Cogn. Psychol., vol. 22, no. September 2007, pp. 877895, 2007, doi: 10.1002/acp.

[27] R. Moreno and A. Valdez, "Cognitive load and learning effects of having students Organize Pictures and Words in Multimedia Environments: The Role of Student Interactivity and Feedback," Educ. Technol. Res. Dev., vol. 53, no. 3, pp. 35-45, 2005.

[28] P. Wouters, H. K. Tabbers, and F. Paas, "Interactivity in videobased models," Educ. Psychol. Rev., vol. 19, no. 3, pp. 327342, 2007, doi: 10.1007/s10648-007-9045-4.

[29] J. M. Boucheix and E. Schneider, "Static and animated presentations in learning dynamic mechanical systems," Learn. Instr., vol. 19, no. 2, pp. 112-127, 2009, doi: 10.1016/j.learninstruc.2008.03.004.

[30] L. Lin and R. K. Atkinson, "Using animations and visual cueing to support learning of scientific concepts and processes," Comput. Educ., vol. 56, no. 3, pp. 650-658, 2011, doi: 10.1016/j.compedu.2010.10.007.

[31] Raihani, Creating Multicultural Citizens: A portrayal of contemporary Indonesian Education. New York: Routletge, 2014.

[32] R. E. Mayer and R. Moreno, "Nine ways to reduce cognitive load in multimedia learning," Educ. Psychol., vol. 38, no. 1, pp. 43-52, 2003, doi: 10.1207/S15326985EP3801_6. 